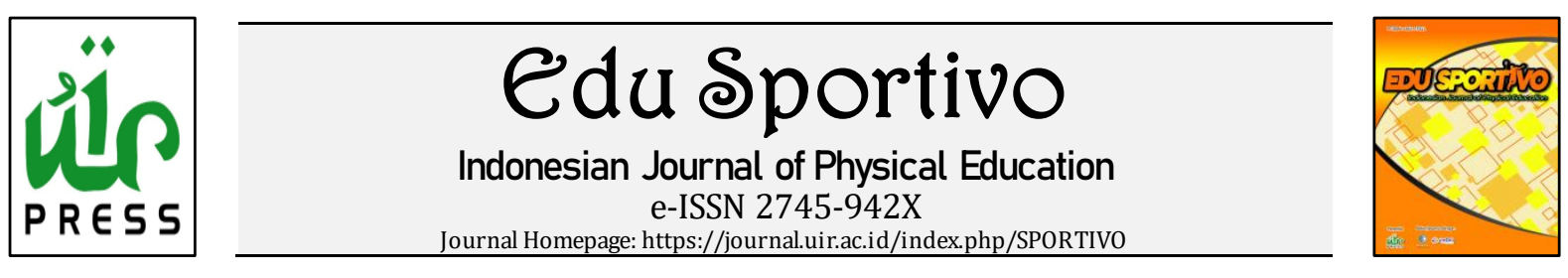

\title{
Pengaruh latihan back-up terhadap kemampuan menyundul bola
}

\section{Back-up training effects to the students' ability in heading the ball}

\author{
${ }^{* 1}$ Dilli Dwi Kuswoyo, ${ }^{2}$ Carolus Wasa, ${ }^{3}$ M. Fadli Dongoran
}

*1,2,3 Pendidikan Jasmani Kesehatan dan Rekreasi, Universitas Musamus, Merauke, Indonesia

Received: 25 June 2020; Accepted 05 August 2020; Published 10 August 2020

\begin{abstract}
ABSTRAK
Tujuan penelitian iniadalah untuk mengetahui ada tidaknya pengaruh latihan back up terhadap kemampuan menyund ul bola pada siswa putra kelas VIII SMP YPK Merauke. Metode eksperimen digunakan untuk penelitian ini dengan pola pretest dan post-test. Dalam pelaksanaan penelitian ini, populasi digunakan yaitu seluruh siswa kelas VIII SMP YPK Merauke Tahun Pelajaran 2019-2020. Adapun jumlah populasi penelitian ini dari setiap masing-masing kelas, di antaranya; Kelas VIIIa berjumlah 28 siswa, VIIIb ada 26 siswa, VIIIc ada 28 siswa, dan kelas VIIId berjumlah 25 siswa. Total keseluruhan populasi ialah 107 siswa. Adapun jumlah sampel dalam penelitian ini ialah; 6 siswa dari kelas VIIIa, 5 siswa dari kelas VIIIb, 6 siswa dari kelas VIIIc, dan dari kelas VIIId ada 5 siswa. Total sampel pada penelitian ini adalah 22 siswa. Instrumen penelitian ini menggunakan tes heading sepakbola. Hasil penelitian ini dapat disimpulkan bahwa latihan back up berpengaruh terhadap hasil sundulan bola siswa. Terbukti dengan siswa yang melakukan latihan back up akan menghasilkan sundulan bola yang baik dibandingkan dengan siswa yang menyundul bola dengan tidak melakukan latihan back up.
\end{abstract}

Kata Kunci: Latihan Back-Up; Menyundul; Sepakbola

*Corresponding Author

Email: kuswoyo_fkip@unmus.ac.id

\section{ABSTRACT}

The purpose of this study was to determine whether there is an effect of back-up training on the ability to head a ball in eighth grade male students of SMP YPK Merauke. The experimental method used for this study was a pre-test and post-test pattern. In the implementation of this research, the population was used, namely all students of class VIII SMP YPK Merauke for the 2019-2020 academic year. The total population of this study from each class, including; Class VIIIa consists of 28 students, VIIIb has 26 students, VIIIc has 28 students, and class VIIId has 25 students. The total population is 107 students. The number of samples in this study are; 6 students from class VIIIa, 5 students from class VIIIb, 6 students from class VIIIc, and from class VIIId there are 5 students. The total sample in this study was 22 students. The research instrument used a soccer heading test. The results of this study can be concluded that the back up exercise has an effect on the results of students' ball headers. It is proven that students who do back up exercises will produce good ball headers compared to students who head the ball without doing back up exercises.

Keywords: Back-Up Training; Heading; Football

Copyright (C) 2020

Edu Sportivo: Indonesian Journal of Physical Education

https://doi.org/10.25299/es:ijope.2020.vol1(1).5190

How To Cite: Kuswoyo, D. D., Wasa, C., \& Donggoran, M. F. (2020). Pengaruh latihan back-up terhadap kemampuan menyundul bola. Edu Sportivo: Indonesian Journal of Physical Education, 1(1), 33-41. https://doi.org/10.25299/es:ijope.2020.vol1(1).5190.

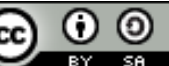

\section{PENDAHULUAN}

Sepakbola merupakan salah satu cabang olahraga terpopuler (Nugraha, 2012; Yulianto, 2020). Sepakbola adalah olahraga beregu yang sangat digemari oleh semua kalangan, baik anak-anak sampai dewasa (Pratama, 2019). Berbagai kalangan begitu menggemarinnya mulai dari putra dan putri, tua, muda, laki-laki, perempuan, mahasiswa, bahkan di dalam pembelajaran formalpun olahraga ini menjadi salah satu materi pembelajaran pada mata pelajaran pendidikan jasmani. Pendidikan jasmani merupakan suatu cabang ilmu yang mempelajari tentang aktivitas gerak melalui media 
olahraga (Rahmatullah, 2019).

Pendidikan jasmani bukan hanya aktifitas fisik yang ditawarkan kepada siswa-siswi di sekolah, lebih dari itu yaitu dengan tujuan dapat meningkatkan mengembangkan kemampuan emosional, sosial, intelektual, dan mental pada siswa melalui aktifitas gerak tubuh (Kuswoyo \& Donggoran, 2019). Rahayu (2013) menambahkan bahwa dengan pendidikan jasmani, siswa akan memperoleh kesan pribadi yang menyenangkan, ungkapan kreatif, inovatif, terampil, kebugaran jasmani, kebiasaan hidup sehat serta memiliki pengetahuan terhadap aktifitas gerak pada manusia

Bermain sepakbola memerlukan teknik dasar yang baik untuk membentuk kerjasama tim sehingga mencapai tujuan dalam permainan yaitu untuk menghasilkan kemenangan. Seorang pemain sepakbola yang tidak memiliki teknik dasar dan keterampilan dasar bermain sepakbola, maka tidak akan mampu menjadi pemain yang baik (Nasution, 2018). Keterampilan sepakbola seseorang dapat ditingkatkan jika sudah menguasai macam-macam teknik dasarnya (Gazali, 2016). Teknik dasar tersebut antara lain; stopping (menghentikan bola), shooting (menendang bola ke gawang), passing (mengumpan), dribbling (menggiring bola), dan heading (menyundul bola) (Kuswoyo, 2018).

Menyundul bola merupakan teknik dasar yang digunakan oleh setiap pemain dalam mengumpan bola kepada teman serta dapat juga digunakan untuk mencetak gol ke gawang lawan. Pentingnya keahlian menyundul bola dalam permainan sepakbola yaitu dapat digunakan untuk mencetak gol, menghalau bola di daerah pertahan sendiri, serta mengoper bola kepada teman (Rismoko et al., 2013). Hasil menyundul bola yang jauh, tepat dan dapat mencetak gol ke dalam gawang lawan, seorang pemain dapat melakukannya dengan menggunakan beberapa macam bentuk latihan yang berkaitan dengan hasil menyudul bola yang efektif dan efisien. Salah satu bentuk latihannya adalah latihan back up. Dalam hasil penelitiannya, Reval (2013) mengungkapkan bahwa penerapan latihan back up mempunyai pengaruh yang bermanfaat terhadap kemampuan heading dalam permainan sepakbola. Menurut Budiwanto bahwa gerakan latihan back up sendiri dapat dilakukan dengan dua cara, yakni dengan mengangkat togok dan mengangkat tungkai kaki (Reval, 2013).

Latihan back up merupakan bagian dari latihan isotonik yang secara khusus melatih kekuatan otot punggung dan otot perut. Dimana punggung adalah bagian penting dalam gerakan heading. Salah satu dasar heading bola ialah badan digerakkan, ditarik ke belakang melengkung pada daerah pinggang. Lalu dengan gerakan seluruh tubuh yaitu kekuatan otot-otot perut, dorongan panggul dan kaki (lutut bengkok diluruskan) badan diayunkan atau dihentakkan ke depan hingga dahi mengenai bola. Bagian tubuh lain yang berperan dalam gerakan menyundul bola yaitu batang tubuh khususnya otot-otot perut. Bagian tengah badan yang berkembang dengan baik selalu dapat menghasilkan gerakan kaki dan lengan semaksimal mungkin (Riadi, 2013). Oleh karenanya, dengan dimilikinya daya ledak otot tungkai, kekuatan otot perut dan kelentukan otot togok yang baik seorang pemain akan mampu menyundul bola dengan posisi meloncat yang semakin jauh (Aprianto, 2009).

Pembelajaran pendidikan jasmani merupakan salah satu mata pelajaran pada siswa kelas VIII siswa SMP YPK Merauke. Dalam kurikulum pembelajaran pendidikan jasmani, teknik menyundul bola merupakan salah satu teknik dasar yang dipelajari oleh siswa. Akan tetapi teknik ini belum sepenuhnya dipahami secara utuh oleh siswa, sehingga masih ada beberapa macam gerakan dan hasil dari menyundul bola pada siswa SMP YPK Merauke yang belum maksimal, maka tujuan dari penelitian ini adalah untuk mengetahui pengaruh latihan back up terhadap peningkatan kemampuan menyundul 
bola siswa. Penelitian ini dianggap penting karena untuk memainkan sepakbola yang baik, diperlukan penguasaan teknik dasar didalamnya dan heading salah satunya. Maka melalui latihan back up siswa akan menghasilkan kemampuan menyundul bola yang maksimal dan terarah.

\section{METODE PENELITIAN}

Penelitian eksperimen ini dilakukan untuk mengumpulkan informasi dengan mengunakan metode eksperimen pola pre test dan post test. Data dalam penelitian ini berasal dari: (a) Data primer yang artinya data yang dikumpulkan atau diolah sendiri oleh peneliti secara langsung dari sumber aslinya, (b) Data sekunder yang artinya data yang diperoleh atau dikumpulkan dari berbagai sumber yang telah ada seperti catatan atau gambar-gambar yang berhubungan dengan masalah yang akan diteliti.

Dalam pelaksanaan penelitian ini, populasi digunakan yaitu seluruh siswa kelas VIII SMP YPK Merauke Tahun Pelajaran 2019-2020. Adapun jumlah populasi penelitian ini dari setiap masing-masing kelas, di antaranya; Kelas VIIIa berjumlah 28 siswa, VIIIb ada 26 siswa, VIIIc ada 28 siswa, dan kelas VIIId berjumlah 25 siswa. Total keseluruhan populasi ialah 107 siswa. Dalam (Hatmoko, 2015) Suharsimi menyatakan bahwa sampel merupakan wakil dari populasi yang akan diteliti. Sampel dalam penelitian ini adalah sebagaian dari jumlah seluruh siswa putra SMP YPK Merauke populasi. Karena populasi dalam penelitian ini berjumlah 107 orang, maka peneliti akan mengambil sebagian jumlah populasi antara 10-15\% atau 20-25\%. Menurut Suharsimi dalam (Kuswoyo \& Betaubun, 2019) jika subjek penelitian kurang dari 100 orang maka keseluruhan dapat menjadi sampel, namun jika lebih dari 100 orang, maka sampel yang dapat diambil adalah $10-15 \%$ atau $20-25 \%$. Sehubungan dengan hal tersebut maka penulis akan mengunakan sebagaian jumlah populasi untuk dijadikan sampel penelitian. Adapun jumlah sampel dalam penelitian ini ialah; 6 siswa dari kelas VIIIa, 5 siswa dari kelas VIIIb, 6 siswa dari kelas VIIIc, dan dari kelas VIIId ada 5 siswa. Total sampel pada penelitian ini adalah 22 siswa. Instrumen penelitian ini menggunakan tes heading sepakbola (Kuswoyo, 2020), adapun langkah-langkah pelaksanaan tes sebagai berikut:

a) Tujuan: Tes ini bertujuan untuk mengukur kecakapan dan keterampilan memainkan bola dengan kepala.

b) Alat dan Perlengkapan

1. Bola sepak satu buah

2. Stopwatch 1 buah

3. Seperangkat alat tulis dan form penilaian

4. Dinding pantul dan dinding sasaran (tembok atau dinding papan yang kuat), minimal sama dengan ukuran untuk tes. Bentuk dan ukuran dapat dilihat pada gambar di bawah ini.

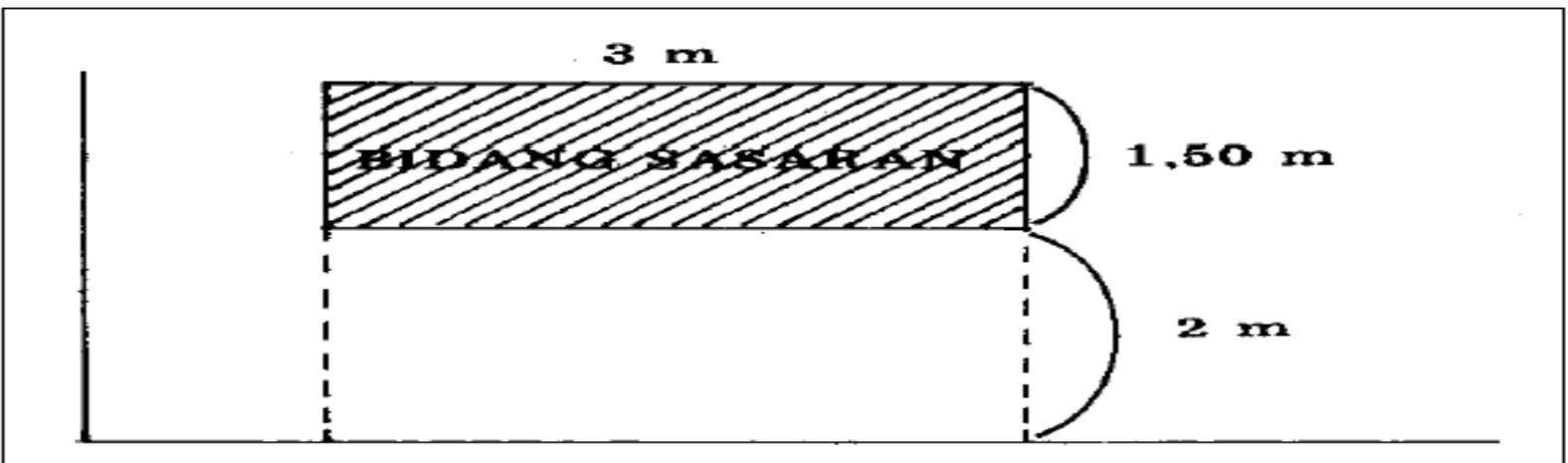

Gambar 1. Dinding Tes Heading 


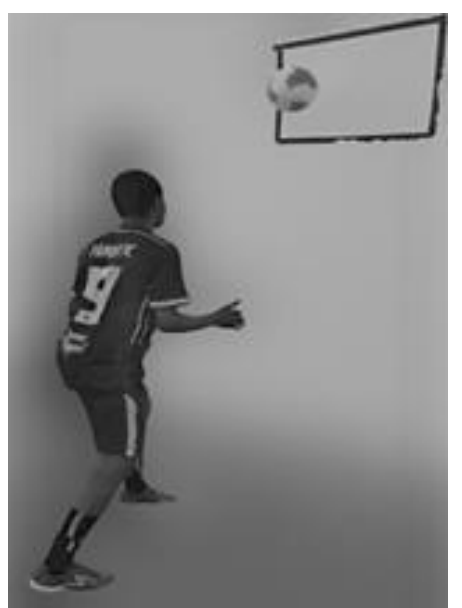

Gambar 2. Posisi Heading

c) Pengetes

1. Pengambil waktu 1 orang.

2. Pengawas merangkap pencatat 1 orang.

d) Pelaksanaan Tes

Pengambil waktu memberi aba-aba SIAP, peserta tes berdiri menghadap ke dinding pantul dengan bola di tangan dalam keadaan siap memulai tes. Pengambil waktu kemudian memberikan aba-aba $Y A$, dan peserta tes segera memantulkan bola ke dinding pantul. Selanjutnya peserta tes memantulkan bola kembali ke dinding dengan menggunakan kepala dan ini harus dilakukan secara terus menerus selama 10 detik. Apabila bola jatuh di tanah, maka peserta tes harus mengambil bola tersebut dan memainkan kembali sampai batas waktu yang telah ditentukan. Bagi pengambil waktu, bersamaan dengan aba-aba YA, stopwatch dijalankan. Tepat 10 detik pengambil waktu memberikan aba-aba STOP dan menghentikan stopwatchnya. Tugas pengawas memperhatikan sundulan bola yang dilakukan peserta tes secara sah dan masuk ke daerah sasaran.

Pengolahan data dalam penelitian ini menggunakan analisis statistik mengunakan rumus regresi linear sederhana, adapun rumusnya sebagai berikut:

$$
\mathbf{Y}=\mathbf{a}+\mathbf{b x}
$$

Keterangan:

Y= Skor kemampuan dalam menyundul bola

$\mathrm{a}=$ Harga $\mathrm{y}$ bila $\mathrm{x}=0$ (harga konstanta)

$\mathrm{b}=$ Angka atau arah nilai koefisien regresi

$\mathrm{x}=$ Latihan back up (Sugiyono, 2012)

\section{HASIL PENELITIAN}

Sebelum melakukan analisis data, peneliti melakukan pre test menyundul bola dengan menggunakan sampel berjumlah 22 orang siswa putra kelas VIII SMP YPK Merauke. Nilai pretest menyundul bola peneliti uraikan pada tabel 1. 
Tabel 1. Skor Menyundul Bola 60 Detik(Pre Test)

\begin{tabular}{cccc}
\hline No. & Nama-NamaSiswa & Hasil Menyundul Bola & Skor \\
\hline 1 & AR & 9 & 45 \\
\hline 2 & AS & 7 & 35 \\
\hline 3 & MAF & 11 & 55 \\
\hline 4 & MI & 10 & 50 \\
\hline 5 & MIM & 12 & 60 \\
\hline 6 & AG & 11 & 55 \\
\hline 7 & MAR & 10 & 50 \\
\hline 8 & MF & 10 & 50 \\
\hline 9 & AIR & 8 & 40 \\
\hline 10 & MZ & 8 & 40 \\
\hline 11 & SL & 10 & 50 \\
\hline 12 & AP & 9 & 45 \\
\hline 13 & IS & 10 & 50 \\
\hline 14 & SB & 12 & 60 \\
\hline 15 & SR & 11 & 55 \\
\hline 16 & AB & 11 & 55 \\
\hline 17 & ABS & 9 & 45 \\
\hline 18 & PS & 9 & 45 \\
\hline 19 & HR & 10 & 50 \\
\hline 20 & ZS & 11 & 55 \\
\hline 21 & WS & 12 & 60 \\
\hline 22 & OS & 10 & 50 \\
\hline & & &
\end{tabular}

Dari hasil pre test yang diperoleh melalui menyundul bola, peneliti selanjutnya menyederhanakan dalam bentuk tabel 2 .

Tabel 2. Persentase Menyundul Bola (Pre Test)

\begin{tabular}{ccc}
\hline Skor Nilai Pretest & Jumlah (Orang) & Persentase (\%) \\
\hline $35-40$ & 3 & 13,63 \\
\hline $41-45$ & 4 & 18,18 \\
\hline $46-50$ & 7 & 31,81 \\
\hline $51-55$ & 5 & 22,72 \\
\hline $56-60$ & 3 & 13,63 \\
\hline Jumlah & $\mathbf{2 2}$ & $\mathbf{1 0 0}$ \\
\hline
\end{tabular}

Berdasarkan tabel di atas, yaitu nilai pre test yang diperoleh siswa sebelum melakukan back up, adalah; jumlah siswa yang memperoleh skor antara 35-40 ada tiga siswa dengan persentase 13,63, skor 41-45 berjumlah 4 orang siswa dengan persentase 18,18, yang mendapat skor 46-50 berjumlah 7 orang siswa pada persentase 31,81, yang mendapatkan skor 51-55 berjumlah 5 orang siswa pada persentase 22, 72, dan nilai 5660 berjumlah 3 orang siswa dengan persentase 13,63. Dari hasil di atas maka dapat peneliti simpulkan bahwa kemampuan menyundul bola pada siswa putra kelas VIII SMP YPK Merauke Tahun pelajaran 2019-2020 masih di bawah rata-rata, sehingga perlu diberikan bentuk latihan yang dapat meningkatkan hasil sundulan bola pada siswa putra kelas VIII SMP YPK Merauke yaitu latihan back up. Pada tabel di bawah ini peneliti akan menjelaskan hasil menyundul bola siswa putra kelas VIII SMP YPK Merauke yang telah diberikan latihan back up untuk meningkatkan hasil menyundul bola. 
Tabel 3. Skor Menyundul Bola 60 Detik (Post Test)

\begin{tabular}{cccc}
\hline No. & Nama & Hasil Menyundul bola & Skor \\
\hline 1 & AR & 11 & 55 \\
\hline 2 & AS & 10 & 50 \\
\hline 3 & MAF & 15 & 75 \\
\hline 4 & MI & 14 & 70 \\
\hline 5 & MIM & 15 & 75 \\
\hline 6 & AG & 13 & 65 \\
\hline 7 & MAR & 14 & 70 \\
\hline 8 & MF & 14 & 70 \\
\hline 9 & AIR & 12 & 60 \\
\hline 10 & MZ & 12 & 60 \\
\hline 11 & SL & 14 & 70 \\
\hline 12 & AP & 13 & 65 \\
\hline 13 & IS & 14 & 70 \\
\hline 14 & SB & 15 & 75 \\
\hline 15 & SR & 14 & 70 \\
\hline 16 & AB & 14 & 65 \\
\hline 17 & ABS & 13 & 65 \\
\hline 18 & PS & 13 & 70 \\
\hline 19 & HR & 14 & 75 \\
\hline 20 & ZS & 14 & 75 \\
\hline 21 & WS & 15 & \\
\hline 22 & OS & 15 & \\
\hline
\end{tabular}

Dari hasil post test yang diperoleh melalui menyundul bola, peneliti selanjutnya menyederhanakan dalam bentuk tabel 4 .

Tabel 4. Persentase Menyundul Bola (Post Test)

\begin{tabular}{ccc}
\hline Skor Nilai Post Test & Jumlah (orang) & Persentase (\%) \\
\hline $50-55$ & 3 & 13,63 \\
\hline $56-60$ & 4 & 18,18 \\
\hline $61-65$ & 7 & 31,81 \\
\hline $66-70$ & 8 & 36,36 \\
\hline Jumlah & $\mathbf{2 2}$ & $\mathbf{1 0 0}$ \\
\hline
\end{tabular}

Uraian yang terdapat pada tabel di atas bahwa nilai post test yang diperoleh siswa setelah melakukan back up, adalah; jumlah siswa yang memperoleh skor antara 50 - 55 berjumlah 3 siswa dengan persentase 13,63\%, ada 4 siswa mendapat skor 56 - 60 dengan persentase 18, 8\%, kemudian dengan persentase $31,81 \%$ terdapat 7 siswa pada skor 61 - 65, yang mendapatkan skor 66 - 70 berjumlah 8 siswa pada persentase $36,36 \%$. Berdasarkan hasil di atas, maka dapat disimpulkan bahwa telah terjadi suatu peningkatan kemampuan menyundul bola pada siswa melalui latihan back up. Skor regresi menyundul bola dapat dilihat pada tabel 5 .

Tabel 5. Skor Regresi Menyundul bola

\begin{tabular}{ccccc}
\hline No & $\begin{array}{c}\text { Menyundul Bola tanpa } \\
\text { Latihan Back up }(\mathbf{X})\end{array}$ & $\begin{array}{c}\text { Menyundul Bola } \\
\text { dengan Latihan } \\
\text { Back up (Y) }\end{array}$ & $\mathbf{X}^{\mathbf{2}}$ & $\mathbf{X Y}$ \\
\hline 1 & 45 & 55 & 2025 & 2475 \\
\hline 2 & 35 & 50 & 1225 & 1750 \\
\hline 3 & 55 & 75 & 3025 & 4125 \\
\hline 4 & 50 & 70 & 2500 & 3500 \\
\hline
\end{tabular}




\begin{tabular}{ccccc}
\hline No & $\begin{array}{c}\text { Menyundul Bola tanpa } \\
\text { Latihan Back up (X) }\end{array}$ & $\begin{array}{c}\text { Menyundul Bola } \\
\text { dengan Latihan } \\
\text { Back up (Y) }\end{array}$ & $\mathbf{X}^{\mathbf{2}}$ & $\mathbf{X Y}$ \\
\hline 5 & 60 & 75 & 3600 & 4500 \\
\hline 6 & 55 & 65 & 3025 & 3575 \\
\hline 7 & 50 & 70 & 2500 & 3500 \\
\hline 8 & 50 & 70 & 2500 & 3500 \\
\hline 9 & 40 & 60 & 1600 & 2400 \\
\hline 10 & 40 & 60 & 1600 & 2400 \\
\hline 11 & 50 & 70 & 2500 & 3500 \\
\hline 12 & 45 & 65 & 2025 & 2925 \\
\hline 13 & 50 & 70 & 2500 & 3500 \\
\hline 14 & 60 & 75 & 3600 & 4500 \\
\hline 15 & 55 & 70 & 3025 & 3850 \\
\hline 16 & 55 & 70 & 3025 & 3850 \\
\hline 17 & 45 & 65 & 2025 & 2925 \\
\hline 18 & 45 & 65 & 2025 & 2925 \\
\hline 19 & 50 & 70 & 2500 & 3500 \\
\hline 20 & 55 & 70 & 3025 & 4125 \\
\hline 21 & 60 & 75 & 3600 & 4500 \\
\hline 22 & 50 & 75 & 2500 & 3750 \\
\hline Total & $\mathbf{1 1 0 0}$ & $\mathbf{1 4 9 5}$ & $\mathbf{5 5 9 5 0}$ & $\mathbf{7 6 3 2 5}$ \\
\hline & & & & \\
\hline
\end{tabular}

Sehingga persamaan regresi linear yg didapat yaitu: $Y=-14,94+1,65$, dan persamaan garis regresi sebagai berikut: Skor regresi menunjukan bahwa; (1) latihan back up mempunyai pengaruh positif terhadap keterampilan menyundul bola (koefisien regresi (a) =1,65). Artinya, jika latihan back up dilakukan secara continue maka semakin baik pula kemampuan menyundul bola. (2) Jika latihan back up tidak dilakukan sama dengan 0 , maka nilai konstanta (b) kemampuan menyundul bola sebesar -14,94. Maka dapat disimpulkan bahwa hipotesis alternatif ( $\mathrm{Ha}$ ) adanya pengaruh latihan back up terhadap kemampuan menyundul bola dalam permainan sepakbola pada siswa diterima.

\section{PEMBAHASAN}

Penelitian ini memiliki tujuan untuk mengetahui pengaruh latihan back up terhadap peningkatan kemampuan menyundul bola siswa. Pada tahun 2013 silam, Reval yang pada hasil penelitiannya menunjukkan bahwa untuk tes latihan fisik diperoleh adanya pengaruh latihan back up terhadap kemampuan heading dalam permainan sepakbola pada siswa MTs Alkhairaat Pinotu Kabupaten Parigi Moutong (Reval, 2013). Kemudian menjelaskan bahwa latihan back up adalah latihan untuk meningkatkan kekuatan otot punggung. Back up melatih otot punggung pemain, punggung berfungsi sebagai pendorong tubuh saat melakukan heading ke depan, saat pemain melakukan heading, jika dirongan yang kuat dari punggung akan menghasilkan heading yang kuat dan jauh. Maka berdasarkan hasil (Bagus, 2017) perhitungan regresi sederhana di atas, dapat diketahui bahwa; (1) Latihan back up berpengaruh positif pada kemampuan menyundul bola, yang berarti bahwa semakin lama seorang melakukan latihan back up maka akan menghasilkan hasil menyundul bola dengan baik. (2) Jika seorang siswa tidak melakukan latihan back up sama dengan 0, maka kemampuan menyundul bola adalah sama dengan $-14,94$ yang berasumsi bahwa variabel-variabel lain yang dapat mempengaruhi dianggap tetap.

Hal ini membuktikan bahwa adanya pengaruh latihan back up terhadap kemampuan menyundul bola dalam permainan sepakbola pada siswa kelas VIII SMP YPK Merauke tahun pelajaran 2019-2020 dan hipotesis alternatif (Ha) diterima. Hasil kedua 
penelitian ini menunjukkan bahwa latihan fisik seperti back up memberikan pengaruh terhadap kemampuan siswa dalam menyundul bola.

\section{KESIMPULAN}

Hasil penelitian ini dapat disimpulkan bahwa latihan back up berpengaruh terhadap hasil sundulan bola siswa. Terbukti dengan siswa yang melakukan latihan back up akan menghasilkan sundulan bola yang baik dibandingkan dengan siswa yang menyundul bola dengan tidak melakukan latihan back up. Hal ini terjadi karena siswa lebih memahami teknik menyundul bola dan cara menghasilkan hasil sundulan bola dengan baik melalui latihan back up. Dengan ditemukannya hasil penelitian ini, maka program latihan fisik seperti back up sangat cocok untuk meningkatkan kemampuan heading bagi siswa dalam bermain sepakbola.

\section{DAFTAR PUSTAKA}

Aprianto, S. (2009). Sumbangan Kekuatan Otot Perut, Kelentukan Togok dan Daya Ledak Otot Tungkai Terhadap Kemampuan Menyundul Bola dengan Posisi Meloncat pada Pemain PS UNNES (Universitas Negeri Semarang). Skripsi. Universitas Negeri Semarang.

Arikunto, S. (2010). Prosedur Penelitian: Suatu Pendekatan Praktik (Edisi Revisi). Jakarta: PT. Rineka Cipta.

Bagus, R. A. (2017). Pengaruh latihan sit up, back up dan flexibility terhadap peningkatan jauhnya heading pada siswa SSB KKK Klajuran Godean kelompok usia 13 - 15 tahun. Jurnal Pendidikan Kepelatihan Olahraga, 1(6), 12-19.

Gazali, N. (2016). Pengaruh Metode Kooperatif dan Komando Terhadap Keterampilan Teknik Dasar Bermain Sepakbola. Journal Sport Area, 1(1), 56-62.

Hatmoko, J. . (2015). Survei Minat dan Motivasi Siswa Putri Terhadap Mata Pelajaran Penjasorkes di SMK Se-Kota Salatiga Tahun 2013. Journal of Physical Education, Sport, Health and Recreations, 4(4), 1729-1736.

Kuswoyo, D. (2018). Identifikasi Tingkat Keterampilan Sepakbola Siswa Putra Kelas V SDN Monta Kecamatan Monta Kabupaten Bima Tahun Ajaran 2018-2019. Jurnal Ilmu Keolahragaan, 17(2), 6-10.

Kuswoyo, D. D. (2020). Buku Ajar Sepakbola. Penerbit NEM.

Kuswoyo, D. D., \& Betaubun, P. (2019). Relationship between speed with dribbling skills on the students of physical education department in playing football at Universitas Musamus. International Journal of Advanced Research in Engineering and Technology, 10(6), 49-52. https://doi.org/10.34218/IJARET.10.6.2019.006

Kuswoyo, D. D., \& Donggoran, M. F. (2019). Identifikasi Tingkat Kemampuan Dasar Permainan Sepakbola Mahasiswa Penjaskesrek. Musamus Journal of Physical Education and Sport (MJPES), 2(1), 28-32. 
Nasution, A. (2018). Survei Teknik Dasar Berman Sepakbola Pada Siswa SMKT SOMBA OPU Kabupaten Gowa. Jurnal Ilmu Keolahragaan,2(1), 1-10.

Nugraha, A. C. (2012). Mahir Sepakbola. Nuansa Cendekia.

Pratama, R. R. (2019). Pengaruh Gizi, Motivasi dan Percaya Diri Terhadap Prestasi Atlet Sepakbola Universitas Sriwijaya. Journal Of Sport Education (JOPE), 1(2), 37-42.

Rahayu, E. . (2013). Strategi Pembelajaran Pendidikan Jasmani (1st ed.). Bandung: CV. Alfabeta.

Rahmatullah, M. I. (2019). Pengembangan Konsep Pembelajaran Literasi Digital Berbasis Media E-Learning Pada Mata Pelajaran PJOK di SMA Kota Yogyakarta. Journal of Sport Education (JOPE), 1(2), 56-65.

Reval. (2013). Pengaruh Latihan Back Up Terhadap Kemampuan Heading dalam Permainan Sepakbola Siswa Mts Alkhairaat. Tadulako Journal Sport Sciences And Physical $\quad$ Education, 1(3), 15. http://jurnal.untad.ac.id/jurnal/index.php/PJKR/article/view/2166/1375

Riadi, M. (2013). Teknik Menyundul Bola dalam Sepakbola. https://www.kajianpustaka.com/2012/12/teknik-menyundul-bola-dalamsepakbola.html

Rismoko, A., Waluyo, M., \& Sutardji. (2013). Sumbangan Hiperekstensi Togok, Kekuatan Otot Perut, dan Leher Terhadap Kemampuan Heading. Journal of Sport Sciences and Fitness, 2(3), 7-12.

Sugiyono. (2012). Metode Penelitian Kuantitatif, Kualitatif dan R\&D. Bandung: CV. Alfabeta.

Widiastuti. (2015). Tes dan Pengukuran Olahraga. Jakarta: Rajawali Pers.

Yulianto, W. W. E. (2020). Identifikasi keberbakatan sepak bola pada siswa sekolah sepak bola hizbul wathan Yogyakarta. Journal of Sport Education (JOPE), 2(2), 4754. 